\title{
Erratum to: Epidemiology, Pathogenesis, and Management of Clostridium difficile Infection
}

\author{
Rajaraman Durai
}

Published online: 19 June 2010

(C) Springer Science+Business Media, LLC 2010

Erratum to: Dig Dis Sci (2007) 52:2958-2962

DOI 10.1007/s10620-006-9626-y

Figure $2 \mathrm{~B}$ in this article was incorrectly attributed as "Courtesy of Dr. Manual Mah," but should have been credited to Drs. Tom Denmark and Edward Friedlander.

The online version of the original article can be found under doi:10.1007/s10620-006-9626-y.

R. Durai $(\varangle)$

Department of Surgery, The Royal London Hospital,

Whitechapel, London E1 1BB, UK

e-mail: dr_durai@yahoo.com 